MoNIKA BoROWIEC-GabRYŚ

Uniwersytet Pedagogiczny w Krakowie, Polska - Pedagogical University of Krakow, Poland

\title{
Święty Maksymilian Maria Kolbe jako menadżer i przedsiębiorca w kontekście przedsiębiorczości personalistycznej
}

\section{Saint Maksymilian Maria Kolbe as a manager and entrepreneur in personalistic entrepreneurship contexst}

Streszczenie: Problematyka przedsiębiorczości sprzyja kształtowaniu postaw etycznych gospodarowania przestrzenią i w przestrzeni społeczno-gospodarczej. Bardzo istotne w tym procesie jest kształtowanie postaw etycznych i patriotycznych poprzez egzemplifikowanie treści teoretycznych działalnością i postawami wielkich Polaków, którzy swoim życiem udowodnili zgodność podejmowanych innowacyjnych przedsięwzięć z wyznawanymi wartościami i przyjętym nadrzędnym celem. Przedmiotem artykułu są cechy przedsiębiorcze i umiejętności organizacyjne oraz znaczenie nadrzędnego celu w realizacji przedsięwzięć społeczno-gospodarczych. Jego celem jest przedstawienie implikacji społeczno-gospodarczych wiary chrześcijańskiej i przedsiębiorczości celowej na wybranych przykładach, zwłaszcza św. Maksymiliana Marii Kolbego jako wzoru dla przedsiębiorców i menadżerów, na podstawie studiów literaturowych. Jego kult na świecie i w Polsce rozwija się głównie na podstawie podjętej przez niego heroicznej decyzji oddania życia za współwięźnia w hitlerowskim obozie koncentracyjnym w Auschwitz, natomiast znikoma jest wiedza na temat jego niezwykłego życia i wielkich talentów przedsiębiorczych. Przedstawiona problematyka może stać się inspiracją dla nauczycieli różnych szczebli kształcenia do podjęcia dyskusji lub pogłębionych prac badawczych na temat etycznych aspektów prowadzenia działalności gospodarczej, a przede wszystkim wyznaczania i realizowaniu celów życiowych oraz prowadzenia życia zintegrowanego.

\begin{abstract}
The idea of entrepreneurship leads to the formation of ethical attitudes in space management and in the socio-economic space. Formation of ethical and patriotic attitudes by exemplifying the theoretical content with the activities and attitudes of great Poles who proved with their lives the compatibility of innovative projects with professed values and the adopted superior goal is very important in this process. The paper is devoted to entrepreneurial qualities and organisational skills, as well as the meaning of the overarching goal in the implementation of socio-economic projects. Its aim is to present the socio-economic implications of Christian faith and purposeful entrepreneurship based on selected examples, in particular using saint M.M. Kolbe as a model for entrepreneurs and managers based on desk research. Globally and locally, his cult has been growing largely on the basis of his heroic decision to give his life for a fellow prisoner in the Nazi concentration camp in Auschwitz; his extraordinary life
\end{abstract}


and great entrepreneurial talents are rarely mentioned. The presented concepts may inspire teachers at various levels of education to start discussions or in-depth research work on the ethical aspects of running a business, and above all, on setting and achieving life goals and leading an integrated life.

Słowa kluczowe: cechy przedsiębiorcze; przedsiębiorczość celowa; przedsiębiorczość personalistyczna; św. Maksymilian M. Kolbe; święci przedsiębiorcy

Keywords: entrepreneurial features; personalistic entrepreneurship; purposeful entrepreneurship; saint entrepreneurs; saint Maksymilian M. Kolbe

Otrzymano: 30 października 2021

Received: 30 October 2021

Zaakceptowano: 17 listopada 2021

Accepted: 17 November 2021

\section{Sugerowana cytacja/Suggested citation:}

Borowiec, M. (2021). Święty Maksymilian Maria Kolbe jako menadżer i przedsiębiorca w kontekście przedsiębiorczości personalistycznej. Przedsiębiorczość - Edukacja [Entrepreneurship - Education], 17(2), 68-81. https://doi.org/10.24917/20833296.172.5

\section{Wstęp}

Kształtowanie postaw przedsiębiorczych jako jednej z kompetencji kluczowych w Unii Europejskiej ma nie tylko zachęcać młodych ludzi do aktywności społeczno-gospodarczej, ale także rozwijać u nich określone cechy osobowości (Borowiec, Rachwał, 2011). W edukacji konieczne jest zatem postrzeganie przedsiębiorczości jako zespołu cech osobowości, które pozwalają na dobre prowadzenie przedsiębiorstwa i umożliwiają aktywne uczestniczenie w życiu społeczno-gospodarczym, niezależnie od charakteru wykonywanej pracy i zajmowanego stanowiska. Powszechnie przyjmuje się, że człowiek przedsiębiorczy jest kreatywny, nie boi się trudności, podejmowania nowych, nieznanych zadań, nie załamuje się niepowodzeniami, jest chętny do zdobywania wiedzy i nowych umiejętności, potrafi cieszyć się z sukcesów, jest otwarty na otoczenie, ma zdolność do empatii, potrafi dobrze ułożyć sobie stosunki z innymi ludźmi, panować nad swoimi emocjami oraz postępować zgodnie z wartościami etycznymi (Rachwał, 2005). Do kompetencji przedsiębiorczych zalicza się także zestaw określonych umiejętności, takich jak wyszukiwanie i wykorzystywanie szans, które stwarza rynek, zdobywanie, selekcja i przetwarzanie informacji, interpretowanie procesów gospodarczych, umiejętności organizacyjne, podejmowanie ryzyka oraz zdolność do planowania przedsięwzięć i prowadzenia ich dla osiągnięcia zamierzonych celów (Borowiec, Rachwał, 2011; Borowiec-Gabryś, Kilar, Rachwał, 2018). Podkreślić należy, że w edukacji z zakresu przedsiębiorczości coraz większego znaczenia nabiera realizowanie celów wychowawczych, kształtowane postaw etycznych oraz rozumienie zasad solidarności społecznej i odpowiedzialnego biznesu.

Zasadnicze znacznie w kształtowaniu postaw przedsiębiorczych ma sposób wychowania. Dlatego powinniśmy mieć świadomość bardzo dużego wpływu edukacji na kształtowanie osobowości młodego człowieka i odpowiedzialności za przedstawiane pośrednio bądź bezpośrednio wzorce zachowania, wartościowania i dokonywania życiowych wyborów. W doborze treści kształcenia, a także procesie kształtowania kompetencji przedsiębiorczych, decydującą rolę odgrywa nauczyciel. Jak wskazuje K. Chałas (2018: 51), „priorytetowym zadaniem nauczyciela jest towarzyszenie uczniom $\mathrm{w}$ drodze 
aksjologicznej". Ważnym czynnikiem edukacji i wychowania w tym kierunku jest inspirowanie uczniów do pogłębiania wiedzy aksjologicznej poprzez lekturę, dyskusje, poszanowanie i promowanie wzorców godnych naśladowania, a także docenianie postaw przedsiębiorczych w życiu codziennym i gotowości do aktywnego uczestniczenia w życiu społeczno-gospodarczym. Wydaje się, że problematyka przedsiębiorczości sprzyja kształtowaniu postaw etycznych gospodarowania przestrzenią i w przestrzeni społeczno-gospodarczej. Bardzo istotne w tym procesie jest kształtowanie postaw etycznych i patriotycznych młodzieży poprzez egzemplifikowanie treści teoretycznych działalnością i postawami wielkich Polaków, którzy swoim życiem udowodnili zgodność podejmowanych innowacyjnych przedsięwzięć $\mathrm{z}$ wyznawanymi wartościami i przyjętym nadrzędnym celem. Szczególnie cennym jest przybliżanie tych postaci jako ludzi sukcesu w znacznie głębszym wymiarze niż powierzchownie pojmowany, przez co mogliby stawać się tak potrzebnymi współcześnie wzorcami dla młodych ludzi poszukujących swojej drogi życiowej. Wydaje się to bardzo ważne w czasach braku lub rozmycia prawdziwych autorytetów oraz medialnego kreowania pseudoautorytetów (Łażewska, 2013). Na coraz większe zapotrzebowanie na kształtowanie relacji pomiędzy życiem moralnym a biznesem wskazują licznie rozwijające się współcześnie ruchy, stowarzyszenia, organizacje biznesowe, które starają się wprowadzać w życie społeczną naukę Kościoła katolickiego (Borowiec, 2013). Podkreślić należy, że istnieją liczne naukowe opracowania wskazujące na silne implikacje społeczno-gospodarcze wyznawanej wiary oraz poświęcone etyce biznesu, etyce chrześcijańskiej, ekonomii komunii oraz przedsiębiorczości personalistycznej (m.in. Adamczyk, 2008; Alvey, 2000; Annales. Etyka w życiu gospodarczym, 2013; Bay, McKeage, M., McKeage, J., 2010; Borowiec, 2006; Cavanaugh, 2008; Cornwall, Naughton, 2003; Cortright, Naughton, 2002; Galata, 2007; Grochmal, 2017; Gronbacher, 1999; Kędzierski, 2016; Król, Leśniak, 2012; Książek, 2018; Leśniak, 2012; Mariański, 2000; Melé, Fontrodona, 2017; Rogowski, 2002; Weber, 2011; Zarządzanie z ludzka twarza, 2018; Żukowska, 2018).

W świetle przedstawionych rozważań w niniejszym artykule podjęta zostanie problematyka wpływu wyznawanych wartości chrześcijańskich na rozwój przedsiębiorczych inicjatyw, szczególnie na przykładzie działalności Świętego Maksymiliana Marii Kolbego. W obecnym 2021 r. przypada 80. rocznica jego śmierci oraz 100 rocznica śmierci Sługi Bożego Wenantego, który był patronem wydawnictwa utworzonego przez Świętego Maksymiliana. Święty M.M. Kolbe został ustanowiony przez Radnych Sejmiku Małopolskiego patronem Małopolski w 2021 r., podejmowane są też działania na szczeblu rządowym w celu upowszechnienia wiedzy o 80 rocznicy męczeńskiej śmierci tego świętego. Maksymilian Maria Kolbe należy do najbardziej rozpoznawalnych polskich świętych na świecie z powodu męczeńskiej śmieci w Auschwitz - niemieckim nazistowskim obozie koncentracyjnym i zagłady. Podobnie w Polsce jego kult rozwija się głównie na podstawie podjętej przez niego heroicznej decyzji o oddaniu życia za współwięźnia. Natomiast wiedza na temat jego niezwykłego życia, wielkich talentów menadżerskich i przedsiębiorczych jest znikoma nawet wśród ludzi zaangażowanych w życie Kościoła katolickiego. W ostatnich latach pojawiły się publikacje i inicjatywy mające na celu przybliżenie mniej znanej historii działalności świętego, którego ofiara z życia „przyćmiła” inne wielkie życiowe dokonania (Terlikowski, 2017; Ryszka, 2021). Działania te wydają się szczególnie ważne w edukacji z zakresu zarządzania i przedsiębiorczości ze względu na ich rozmach i prekursorski charakter. Wyrazem dostrzeżenia innowacyjności św. M.M. Kolbego jest również inicjatywa grupy polskich biznesmenów mająca na celu rozpropagowanie wiedzy 
na temat przywódczych i organizacyjnych umiejętności świętego oraz zgłoszenie petycji do papieża Franciszka o ogłoszenie franciszkanina patronem start-upów i przedsiębiorców (Gnyszka, 2018). Warto zatem, aby wybitne postawy przedsiębiorcze świętych Kościoła katolickiego, zwłaszcza św. M.M. Kolbego, były rozpropagowywane i znalazły właściwe odzwierciedlenie w procesie edukacji, tym bardziej, że wiele przedsiębiorczych osób, próbując swoich sił w biznesie, poszukuje mentorów i nauczycieli. Celem niniejszego artykułu jest przedstawienie implikacji społeczno-gospodarczych głębokiej wiary chrześcijańskiej i przedsiębiorczości celowej na wybranych przykładach, zwłaszcza św. M.M. Kolbego jako wzoru dla przedsiębiorców i menadżerów. Wydaje się, że problematyka ta mogłaby też stać się pewną inspiracją dla nauczycieli różnych szczebli kształcenia do podjęcia dyskusji lub pogłębionych prac badawczych na temat etycznych aspektów prowadzenia działalności gospodarczej, a przede wszystkim wyznaczania i realizowaniu celów życiowych oraz prowadzenia życia zintegrowanego.

\section{Przywództwo służebne}

Zdaniem J. Schumpetera, cechami przedsiębiorcy są zdolności przywódcze, umiejętność odejścia od utartych ścieżek i odporność na krytykę. Z kolei przedstawiciele globalnych korporacji zazwyczaj wskazują na inne pożądane cechy pracowników, takie jak umiejętność współpracy, umiejętność podporządkowywania się panującym w organizacji zasadom oraz wąska specjalizacja w zakresie kompetencji (Piontek, 2019). „Zarówno kadra menadżerska, jak i pracownicy nie dążą do wyzwolenia się z przywództwa i preferują autokratyczny system zarządzania” (Piontek, 2019: 72, za: Haromszeki, Jarko, 2014). Jednakże, jak podkreśla M. Napiórkowski, „władza bez autorytetu niesie ryzyko podążenia w stronę tyranii [...] prawdziwy autorytet powinien łączyć wiedzę i doświadczenie z konsekwencją i życiem w zgodzie z określonymi wartościami” (Napiórkowski, 2021). Współcześnie odchodzi się od przywództwa opartego na autorytecie formalnym, czyli wynikającym z zajmowanego stanowiska na rzecz modelu przywództwa opartego na autorytecie nieformalnym (Jacko, 2007). Liderom, którzy cieszą się autorytetem, łatwiej motywować zespół, budować kapitał społeczny, wprowadzać nowe rozwiązania, rozwiązywać problemy, radzić sobie z kryzysami, podejmować odważne decyzje, co zarazem pozwala na szybsze, łatwiejsze i tańsze osiągnięcie zamierzonych celów. Przestrzega się jednak zwykle przed zbytnią ryzykownością decyzji, wskazując na wartość pokory w dobrym przywództwie. Tworzenie właściwej organizacji pracy, zwiększanie innowacyjności, ulepszanie struktur społecznych i gospodarczych powinno uświadamiać dużą odpowiedzialność za wpływ wywierany zarówno na poszczególnych ludzi, jak i na system społeczno-ekonomiczny. Skutkować to powinno rozwojem przywództwa służebnego i umiejętności rozeznawania (Greenleaf, 1970; Parris, Peachey, 2013).

Warto również zaznaczyć, że podstawą zdolności innowacyjnych jest bardzo szeroki zakres wiedzy użytecznej i „nieużytecznej” z różnorodnych dziedzin nauki, który umożliwia wszechstronny rozwój i poszukiwanie interdyscyplinarnych, przełomowych rozwiązań (Piontek, 2019). Niejednokrotnie wiedza tzw. „niezwiązana z życiem”, „niepraktyczna” kształtuje umiejętności logicznego myślenia, dedukcji i system wartości moralnych, tak ważnych w prowadzeniu przedsięwzięć społeczno-gospodarczych.

Badania B. Przybylskiego (2013) wskazują na zapotrzebowanie na autorytety w procesie edukacji. Autor stawia pytania dotyczące źródła kryzysu autorytetów i rozważa, 
czy leżą one po stronie jednostek, które nie chcą lub nie szukają osób godnych zaufania, czy też w instytucjach państwowych, religijnych i szkolnych, które nie kształtują osób o wybitnym i niekwestionowanym autorytecie. Wydaje się, że współcześnie szczególną rolę w tym procesie odgrywają media. Podobnie S. Kowalik wskazuje, że „dzięki odpowiednim działaniom autorytetów medialnych może dojść do wykreowania pseudoautorytetów społecznych, czyli takich ludzi, których obdarza się wyjątkowymi przymiotami, podczas gdy w rzeczywistości nie posiadają oni jakiejkolwiek charyzmy" (Kowalik, 2006: 195). Przez to mogą stawać się oni formą kompensacji braku wzorów osobowych w życiu społecznym. W nawiązaniu do koncepcji M. Webera (2004) wyróżnia on trzy możliwe powody zaniku lub słabości autorytetów w życiu społecznym. Po pierwsze, brakuje ludzi z odpowiednią charyzmą przy istniejącym zapotrzebowaniu społecznym na obecność postaci znaczących w życiu publicznym. Po drugie, zmiany świadomości społecznej doprowadziły do zaniku tradycji, w ramach której mogłoby dojść do kreowania autorytetów. Po trzecie, następuje silna korozja formalnych instytucji społecznych, zwłaszcza systemu prawa, i struktury państwa nie są zdolne do zagwarantowania autorytetów. Potęga mediów w upowszechnianiu wiedzy o autorytetach polega na wykorzystaniu trzech mechanizmów społecznych: dostrzegalności, rezonansu i legitymizacji przywódcy (Kowalik, 2006). Dostrzegalność autorytetu uzależniona jest od obszaru, na którym działają media kreujące dany autorytet, oraz intensywności pojawiania się tego autorytetu w mediach. Im obszar dostępności medialnego autorytetu jest większy, tym większe są szanse na to, że dany przywódca ruchu społecznego stanie się jego symbolem. Rezonans określany jest jako wielkość reakcji zwolenników i przeciwników na prezentowany w mediach autorytet, co jest zależne przede wszystkim od sposobu przedstawienia, a nie od faktycznych walorów przywódcy. Legitymizacja medialnego autorytetu zależy od dopasowania poglądów przywódcy do oczekiwań odbiorców i im większe będzie to dopasowanie, tym większa będzie szansa na utrwalenie w świadomości społecznej medialnego bohatera. Podkreślić należy, że środki masowego przekazu filtrują informacje o przywódcy, co powoduje, że przekazywana wiedza o jego poglądach nigdy nie jest pełna i świadomie bądź nieświadomie może być zniekształcona.

Do problematyki przywództwa odnosi się dokument pt. Powołanie lidera biznesu, w którym po raz pierwszy Kościół katolicki zwraca się wprost do liderów biznesu oraz wszystkich uczestników życia gospodarczego, zapraszając ich do refleksji nad ich powołaniem oraz misją, jaką mają do zrealizowania w świecie pełnym napięć społeczno-gospodarczych (Borowiec, 2013). Jak sugerują jego autorzy, może stać się pewną pomocą dla nauczycieli przedsiębiorczości przez inspirowanie uczniów i studentów do podejmowania działalności gospodarczej zgodnej z zasadami nauki społecznej Kościoła oraz pogłębionej refleksji nad powołaniem zawodowym. W dokumencie sformułowano zasady biznesu dla trzech wyróżnionych celów przedsiębiorczości, za które uznano zaspokojenie potrzeb świata przez tworzenie towarów oraz rozwój usług, organizowanie dobrej i wydajnej pracy oraz tworzenie trwałego bogactwa i jego sprawiedliwy podział (Papieska Rada IUSTITIA ET PAX, 2012). W dokumencie sformułowano następujące postulaty w odniesieniu do liderów biznesu:

1. Podejmowanie znaczących przedsięwzięć przez ludzi świadomych swojego wpływu na przemiany społeczno-gospodarcze.

2. Wierność zasadom i prawe przywództwo w przedsiębiorstwie.

3. Postawa służby i dzielenia. 
4. Oferowanie produktów i usług, które zaspokajają autentyczne ludzkie potrzeby.

5. Tworzenie dobrobytu w zrównoważony sposób.

6. Organizowanie dobrej i wydajnej pracy, m.in. przez właściwy stosunek do pracownika i odpowiedni system motywacji.

7. Tworzenie firmy jako wspólnoty osób, które łączą prawidłowe relacje.

8. Zdrowe środowisko moralno-kulturowe. Uznanie podstawowych norm moralnych i szanowanie godności człowieka.

\section{Wybrani święci i błogosławieni przedsiębiorcy}

W nawiązaniu do przedstawionych rozważań w niniejszym artykule odwołamy się tylko do kilku świętych i błogosławionych przedsiębiorców, w których życiu dostrzeżono heroiczność cnót i którzy mogliby się stać inspiracją dla współczesnych przedsiębiorców. Wśród bardzo dużej liczby osób (1343 błogosławionych i 482 świętych) wyniesionych na ołtarze przez św. Jana Pawła II jest zaledwie 30 osób świeckich, a wśród nich tylko kilku przedsiębiorców i menadżerów ukazanych jako oficjalne wzory do naśladowania w zakresie przedsiębiorczości. Są to: bł. Edmund Ignacy Rice, bł. Józef Tovini, bł. Stanisław Kostka Starowieyski, bł. Zefiryn Giménez Malla, bł. Wincenty Vilar David (Piątek, 2020). Życiorys każdej z tych postaci mógłby stać się inspiracją do rozważań na temat przedsiębiorczości i źródeł ponadczasowych sukcesów. Poza nimi powszechnie jako święci przedsiębiorcy wskazywani są m.in.: św. Benedykt i św. Ignacy Loyola.

Święty Benedykt (480-547) opracował powszechnie znaną zasadę Ora et labora („Módl się i pracuj”), która dzieli dzień na trzy części: osiem godzin na modlitwę (rozwój duchowy), osiem na pracę (realizację celów) i osiem na odpoczynek (regenerację). To ponadczasowa propozycja dla tak współcześnie potrzebnej równowagi między życiem prywatnym a życiem, zawodowym określanej jako work-life balance (Foks, 2017). Poza tym jego wielką pracę dla ocalenia i rozwoju spuścizny starożytności inspirowaną regułą św. Bazylego można rozważać w kategorii transferu wiedzy czy wydajności pracy.

Kolejny święty - założyciel jezuitów, św. Ignacy Loyola (1491-1556) jest uważany za twórcę współczesnej koncepcji przywództwa. Przyjmuje się, że ignacjańska ścieżka formacji do przywództwa to przepis na rozwój biznesu poprzez liderów zmotywowanych wewnętrznie, odpowiedzialnych i godnych zaufania.

Następne postaci to wspomniani błogosławieni Kościoła katolickiego. Pierwszy z nich to bł. Edmund Ignacy Rice (1762-1844) - Irlandczyk o zdolnościach przedsiębiorczych i organizacyjnych, który widząc ogromne potrzeby edukacyjne młodzieży, zadecydował się przeznaczyć odziedziczony majątek dla biednych. Po ukończeniu edukacji rozpoczął praktykę u swojego wuja, który był zaangażowany w zaopatrzenie statków w Waterford i szybko nabył umiejętności w zakresie handlu, rozwinął ten rodzinny biznes i podpisał lukratywny kontrakt na dostawy mięsa dla armii brytyjskiej. Jednakże nagła śmierć jego ciężarnej żony i pozostawienie go z niepełnosprawną córeczką miało wpływ na poszukiwanie głębszego sensu w życiu. W konsekwencji sprzedał on przedsiębiorstwo handlowe i założył Zgromadzenie Braci Chrześcijańskich, tworzył szkoły w Irlandii i wielu innych krajach (nawet w Indiach, Ameryce, Australii), a zatem, jak można powiedzieć w pewnym uproszczeniu, oddał się działaniom na rzecz podnoszenia jakości kapitału ludzkiego i społecznego. 
Następny błogosławiony to Józef Tovini (1841-1897), skuteczny inwestor i zarządca. Był on włoskim prawnikiem, bankowcem i burmistrzem, ojcem dziesięciorga dzieci. Często mawiał „Nasze dzieci bez wiary nigdy nie będą bogate, z wiarą nigdy nie będą biedne”. Założył on trzy banki, dając tym samym niezależność inwestycjom, które uważał za ważne, oraz dziennik katolicki. Jako burmistrz zlikwidował zadłużenie podlegającego mu miasteczka, a nawet rozpoczął budowę linii kolejowej. Zarządzał wielkim majątkiem, ale żył skromnie, gdyż znał swój „cel biznesowy”.

Kolejny wybitny zarządca to bł. Kostka Starowieyski (1895-1941), który niedługo po rozpoczęciu studiów prawniczych na Uniwersytecie Jagiellońskim został wcielony do wojska. Do rezerwy przeszedł w stopniu kapitana z licznymi medalami i nie wrócił do studiowania prawa, ale ukończył kurs rolniczy i został zarządcą majątków ziemskich. Był ojcem sześciorga dzieci. K. Starowiejski potrafił jednoczyć społeczność wokół wspólnych celów i budował partnerskie relacje z każdym, bez względu na status społeczny. Takie budowanie głębokich, uczciwych relacji biznesowych jest bardzo ważnym wyzwaniem stojącym przed przedsiębiorcami. Liczne akcje charytatywne i społeczne Starowiejskiego (zorganizował m.in. ośrodek szkoleniowo-rekolekcyjny, koło porad sąsiedzkich, salę teatralną dla Kółka Miłośników Sceny, Koła Inteligencji Katolickiej, współorganizował diecezjalny Kongres Eucharystyczny w Chełmie, działał w Akcji Katolickiej) pokazują, że trwałe przedsiębiorstwo można zbudować poprzez mocne zaangażowanie i wszechstronną pozabiznesową działalność. Nawet w nazistowskim obozie w Dachau prowadził działalność apostolską. Tam też został zamordowany przez funkcjonariuszy obozowych.

Następny znaczący przedsiębiorca to Zefiryn Giménez Malla (1861-1936), który jest pierwszym przedstawicielem narodowości romskiej ogłoszonym błogosławionym Kościoła katolickiego i patronem wszystkich Romów. Był on ekspertem w handlu końmi, mułami i osłami, a swoją pracę wykonywał z wielkim zaangażowaniem i dobrocią dla zwierząt. Określany był jako rzecznik pokoju ze względu na wyjątkowy dar pokojowego rozstrzygania kwestii spornych pomiędzy Romami a miejscową ludnością. Wspierał ubogich, chorych i potrzebujących duchowego wsparcia, należał do stowarzyszenia charytatywnego św. Wincentego à Paulo oraz do trzeciego zakonu św. Franciszka. Brał czynny udział w życiu religijnym swojego miasta. Odznaczał się szczególnym nabożeństwem do Matki Bożej, z powodu noszenia różańca został też aresztowany i zamordowany.

Kolejny błogosławiony przedsiębiorca to Wincenty Vilar David (1889-1937), inżynier i właściciel fabryki wyrobów cukierniczych. Podjął on studia w Barcelonie, zakończone doktoratem. Podporządkowując się testamentowi zmarłego ojca, przejął rodzinną fabrykę. Wprowadzał w niej zasady społecznej nauki Kościoła katolickiego i bronił interesów robotników. Kiedy po powstaniu Republiki Hiszpańskiej usunięto ze szkół lekcje religii, zorganizował Parafialny Patronat Akcji Katolickiej w obronie praw rodziców do wychowania swoich dzieci. W okresie hiszpańskiej wojny domowej udzielał schronienia duchownym i zakonnicom. Aresztowany przez trybunał rewolucyjny, miał zostać zwolniony za cenę wyrzeczenia się wiary katolickiej. Oświadczył jednak: „Najbardziej chlubię się tym, że mogę być, kim jestem, i postępować tak, jak postępowałem. Nie zaprę się prawdy", a przed egzekucją wybaczył swoim prześladowcom.

Wydaje się, że warto również wspomnieć i szerzej pochylić się w pracach badawczych i edukacyjnych nad postacią Leona Harmela (1829-1915) - francuskiego pioniera przedsiębiorczości personalistycznej, działacza społecznego, autora Katechizmu przedsiębiorcy, 
człowieka, który z całą powagą potraktował działalność biznesową jako drogę do świętości i uważany jest za wzór chrześcijańskiego pracodawcy.

Powyższe przykłady pokazują, że możliwe jest łącznie wyznawanych wartości chrześcijańskich z aktywnością społeczno-gospodarczą. Etyczne prowadzenie działalności gospodarczej może przynosić korzyści, a życie w prawdzie i ukierunkowanie na właściwy, nadrzędny cel przyświecający każdemu przedsięwzięciu, przynosi wymierne i niewymierne korzyści. Warunkiem powodzenia jest wierność zasadom, twórcze zaangażowanie w przekształcanie świata, wrażliwość na potrzeby innych i właściwa hierarchia celów życiowych. W niniejszym artykule zarysowano jedynie sylwetki świętych i błogosławionych, którzy mogą być wskazywani jako wzorce do naśladowania w edukacji z zakresu przedsiębiorczości poprzez pogłębione studia literatury w tym zakresie i głębsze pochylenie nad proponowanymi i wdrażanymi przez nich schematami organizacji pracy oraz zarządzania.

\section{Osiągnięcia menadżerskie i przedsiębiorcze św. M.M. Kolbego}

Święty Maksymilian Maria Kolbe (1894-1941) jest powszechnie znanym franciszkaninem i wielkim świętym Kościoła katolickiego, ale mało rozpoznawalnym jako innowacyjny przedsiębiorca i naukowiec. Był on człowiekiem wszechstronnie wykształconym, interesował się matematyką i fizyką. W 1915 r. obronił doktorat w języku włoskim z filozofii, a w 1919 r. obronił doktorat z teologii na Papieskim Wydziale Teologicznym św. Bonawentury oo. Franciszkanów. Był on aktywnym krótkofalowcem (w 1938 r. uruchomił radiostację), konstruktorem telegrafów i modelu statku kosmicznego. Już w wieku 15 lat wysłał własne projekty urządzeń, takich jak telegraf oraz „aparat zapisujący mowę i głosy natury” do urzędu patentowego we Lwowie, a w 1915 r. do włoskiego urzędu patentowego przesłał projekt pojazdu umożliwiającego loty w kosmos, który nazwał „eteroplanem”. Wyrazem jego innowacyjności jest m.in. utworzenie pierwszego w Polsce katolickiego radia, założenie prężnie działającego wydawnictwa, wydawanie największego polskiego miesięcznika religijnego - „Rycerz Niepokalanej” i „Małego Dziennika”, rozpoczęcie budowy lotniska, stworzenie planów budowy floty morskiej, założenie i zarządzanie sprawnie działającym, największym ówcześnie na świecie, ponad 700-osobowym klasztorem w Niepokalanowie, a także zbudowanie klasztoru w Nagasaki i stworzenie wydawnictwa japońskiego (Foks, 2017). Podkreślał jednak, że „w chwili konania nie będzie nam potrzebna nauka ani głośne czyny, ale uświęcenie duszy” (Przemówienia..., 2020: 275). „Wiedza jest o tyle pożyteczna, o ile służy miłości. Więcej wiedzy szkodzi, bo nadyma" (Przemówienia..., 2020: 342). Jego liczne przedsiębiorcze działania bez jakiegokolwiek wsparcia finansowego i powszechnej akceptacji, zainteresowanie technologicznymi nowinkami i umiejętność praktycznego ich zastosowania w biznesie wynikały z przyjętego życiowego celu, jakim było zdobycie świata dla Niepokalanej. „W połatanym habicie, w połatanych butach, na samolocie najnowocześniejszego typu - jeśli to będzie potrzebne dla zbawienia i uświęcenia większej ilości dusz - oto pozostaje naszym ideałem" pisał z Nagasaki do braci w Niepokalanowie (Szczepański, 1983: 182). Był entuzjastą postępu technicznego, który wykorzystywał w swojej pracy misjonarskiej i publicystycznej. Wiedział jednak, że musi iść on w parze z wewnętrzną pracą, a pogoń za szybkością i wygodą grozi światu katastrofą.

Postęp uwolniony od odpowiedzialności przynosi wiele zagrożeń środowiskowych i jest on uzasadniony, jeśli służy słusznej sprawie. Wielcy święci byli zawsze wielkimi 
realistami i wiedzieli, że każde poważne działanie wymaga dużo ciszy i skupienia, że po sukcesie potrzeba kontemplacji. Niczego nie czynili na pokaz i dla poklasku. Świat według św. M.M. Kolbego przeżywa ostatnią epokę, będącą epoką Maryi, której ofiarował życie i dla której chciał zdobyć cały świat. W 1927 r. na polu pod Warszawą z grupą kilku osób, którym przyświecał wspólny cel, rozpoczął budowę klasztoru-wydawnictwa. Pierwsze budynki stanęły zaledwie w dwa miesiące. W 1937 r. na wydrukowanie wszystkich pism zużyto ponad 1,6 tys. ton papieru i ok. 35 ton farby drukarskiej. Niepokalanów był ośrodkiem celowej, wytężonej, bardzo dobrze zorganizowanej pracy, nowocześnie zorganizowanym zakładem produkcyjnym, zarządzanym według najnowocześniejszych wówczas standardów, którego głównym celem było doprowadzenie do świętości zakonników, następnie odbiorców mediów (Terlikowski, 2017). Duch zakonności zawsze musiał tam wyprzedzać ducha skuteczności i praca nie była celem, ale środkiem do uświęcenia duszy. Warto wspomnieć, że świętość rozumiana była jako nieustanne wykonywanie swoich obowiązków w drodze całkowitego posłuszeństwa i zaangażowania. Święty Maksymilian mówił: „Święty nie jest dziadygą, ciamajdą do popychania. Święty musi być dziarski, rzutki pełen inicjatywy" (Terlikowski, 2017: 507). Współczesnym językiem moglibyśmy powiedzieć, że święty powinien być przedsiębiorczy.

Dzięki św. M.M. Kolbemu Niepokalanów stawał się samowystarczalnym miasteczkiem, które posiadało m.in. gospodarstwa rolne, piekarnie, mleczarnię, szpitalik, ochotniczą straż pożarną, tory kolejowe z bocznicą, budynki przemysłowe, klasztorne zabudowania, trzy boiska do siatkówki, koszykówki itd. Mimo rozmachu przedsięwzięcia praktykowano tam ścisłe franciszkańskie ubóstwo.

Święty M.M. Kolbe dążył do „podboju” świata dla Niepokalanej, dlatego działał w Japonii, rozwijał wydawnictwa, zakładał klasztory i Organizację Rycerstwa Niepokalanej ${ }^{1}$. Wszelkie swoje działania, zaplanowane na globalną skalę, tworzył przy bardzo ograniczonych początkowych zasobach, odznaczał się wielkim zapałem, pracowitością, odwagą i talentami organizacyjnymi. Każde przedsięwzięcie zaczynał własnymi rękami, podejmował odważne działania (np. wydawanie „Rycerza Niepokalanej” w Japonii początkowo bez znajomości języka japońskiego). Był pewny sukcesu, ponieważ wierzył we wszechmoc Boga patronującą jego trudom. Na rok przed wojną wydawnictwo niepokalanowskie było u szczytu rozwoju i „Rycerz Niepokalanej” bił kolejne rekordy nakładu - milion egzemplarzy. Biorąc pod uwagę ówczesny współczynnik poczytności prasy (średnio po jeden numer pisma sięgało nawet pięć osób), wskazywano, że prasa z Niepokalanowa oddziaływała na co najmniej 17\% społeczeństwa (Cymanow-Sosin, 2020). Dyrektor Rycerstwa Niepokalanej przyznawał wówczas, że od samego początku nigdy nie liczył na zysk, ale polegał wyłącznie na Opatrzności Bożej (Kosmana, 2019). W 1938 r. napisał do Izby Przemysłowo-Handlowej w Warszawie: „kapitału żadnego nie posiadamy”, choć jego drukarnia należała do najnowocześniejszych, jeśli nie na świecie, to na pewno w Europie, a Niepokalanów był liczącym się wielkonakładowym wydawnictwem. Maszyny drukarskie wywiezione z Niepokalanowa w 1939 r. do Rzeszy były w użytku aż do lat 70.

\footnotetext{
${ }^{1}$ Podczas pobytu na misjach w Japonii (1931-1935) Kolbe zdecydował, aby na odludziu, na skraju góry, na terenie wymagającym karczowania, wybudować klasztor franciszkanów. Odradzano mu tę lokalizację i sugerowano, aby wybudował klasztor w centrum dzielnicy katolickiej. Jednak dzięki jego decyzji klasztor i jego mieszkańcy ocaleli po zrzuceniu bomb atomowych przez Amerykanów w 1945 r.
} 
Kolbe był przeciwnikiem wygodnictwa, przeciętności, utrzymywania status quo czy „odcinania kuponów” od zdobytego kapitału. W liście do swojego brata w 1926 r. pisał, że celem wydawnictwa jest „staranie, aby zdobyć dla Niej [Niepokalanej - red.] cały świat i każdą duszę z osobna, a nigdy ten «przeklęty» dochód; jak Ci opowiadałem, że jeden z naszych ojców sobie przedstawiał: »już się dalej nie rozwijać, maszyn już dosyć; teraz będziemy mieli sobie dochód «. Ot tak, środek wziąć za cel, a cel za środek... ot folwareczek, tylko w innej formie".

Przyszły święty zdobywał środki nie dla siebie, lecz także na rozwój dzieła, jakim był Niepokalanów. Może płynąć z tego też nauka dla tworzenia planów biznesowych, z których niewiele niestety opiera się na idei „folwareczku”, mającego zaspokajać wyłącznie własne potrzeby i ambicje. Należy pamiętać, że bogactwo nie jest złem, ale każde dobro materialne i duchowe ma wymiar społeczny i jak we wszystkim, w tym zakresie ważna jest wolność od przywiązania do dóbr materialnych. Ale - co istotne - Kolbe mówił, że „największa ofiara to ofiara z własnej woli” (Szczepański, 1983: 184). Święty M.M. Kolbe podkreślał również, aby nie przywiązywać się do niczego: ani do pracy, ani do godności, ani do urzędu, ani do miejsca. Zwracał też uwagę, że ludzie ocenią pracę według wysiłków i widzialnych wyników, ale że Bóg ocenia według intencji, z jaką się pracuje. „Zdarzyć się może, że ktoś intensywnie pracuje i wyniki są widzialne, jest on z tego zadowolony, ale intencja jest mniej czysta. Mimo tych wyników Niepokalana nie będzie zadowolona z tej pracy. Inny znów pragnie jak najlepiej, ale zdrowie mu nie dopisuje, często go karcą i przerzucają z miejsca na miejsce. Trapi się on może, ale Niepokalana się cieszy, bo ma czystą intencję. Może się również zdarzyć, że ktoś bardzo dobrze spełnia obowiązki, ale nie przypisuje sobie tego, ale łasce Bożej. Ten oczywiście ma bardzo dobra intencję i Niepokalana jest również z niego zadowolona” (Przemówienia..., 2020: 379). „Jeśli zatem zdarzy się, że przy najlepszych chęciach wysiłki są nieudane, to nie powinien być to powód do zmartwień. [...] jest naszym obowiązkiem zrobić wszystko, co możemy, do osiągnięcia celu, a jeśli go nie osiągniemy, nie traćmy pokoju” (Przemówienia..., 2020: 323). „Strzeżmy się złudzenia, jakoby owoce działalności zewnętrznej wskazywały na wartość dzieła (Szafrańska, 1983: 128).

Święty M.M. Kolbe był sprawnym menadżerem i organizatorem, można powiedzieć, że był również mistrzem w rekrutacji - z bardzo dużej liczby chętnych dokonywał ścisłej selekcji i wybierał tych, w których dostrzegł największe pragnienie świętości. Posiadał też cechę asertywności, stanowczości i delikatności oraz zwracał dużą uwagę na przeciwdziałanie tworzeniu się koterii.

W kolportażu w jego wydawnictwie stosowano zasadę, którą współcześnie określamy mianem ekonomii wdzięczności - „Rycerz Niepokalanej” miał wydrukowaną cenę, ale był rozdawany w zamian za dobrowolną ofiarę (Operacz, 2017). Jeśli gazeta się komuś nie spodobała, mógł ją oddać i odzyskać pieniądze (gwarancja satysfakcji). Stosowano też popularny dzisiaj crowdsourcing - gazety rozprowadzali dobrze dobrani ludzie: ambasadorowie marki, pokazywano czytelnikom codzienne życie braci, którzy przygotowują dla nich gazety, drukowano kalendarze ze zdjęciami zrobionymi w Niepokalanowie, św. Maksymilian miał także często bardzo bliski kontakt z odbiorcami i odpisywał dokładnie na otrzymane listy. Poza tym św. M.M. Kolbe stosował efektywne zasady zarządzania czasem, np. zakonnicy pracowali łącznie po dziesięć godzin dziennie, również na nocne zmiany, ale ich zajęcia były umiejętnie przeplatane modlitwą i odpoczynkiem. 
Święty M.M. Kolbe w opiniach specjalistów badających rozwój mediów w Polsce jest wizjonerem mediów elektronicznych. Podkreślał on: „Boć doprawdy słusznie powiedział Napoleon, jeszcze przed laty stu, kiedy niewielu jeszcze umiało czytać: "prasa jest piątą potęgą świata «” (Klimek, 2020). Przytaczał słowa Cremieuxa: „Miejcie sobie wszystko za nic, za nic pieniądze, za nic poważanie, prasa jest wszystkim. Mając prasę, będziemy mieli wszystko". Wrogowie chrześcijaństwa rozeznali sytuację i właśnie w antyklerykalnych i antychrześcijańskich ruchach, organizacjach i mediach, obok pychy i konsumpcjonizmu, widział największe zagrożenie i przyczynę laicyzacji świata i tej machinie chciał się przeciwstawić. Ostrzegał on, że możemy budować najwspanialsze kościoły, ale jeśli nie będziemy mieli katolickich mediów, to nasze świątynie zostaną kiedyś puste. Z jednej strony był orędownikiem wkraczania w świat zlaicyzowany, a z drugiej strony wskazywał na ludzi prostych, którzy byli niejako na marginesie ówczesnego świata medialnego. Znał on ówczesną strukturę społeczną, dlatego treści i formę przekazu dostosowywał do odbiorcy. „Bezpośredni kontakt z elitami nie powinien przesłaniać dziennikarzom szerokich warstw społecznych [...] do ludzi trzeba się zbliżać...” (Cymanow-Sosin, 2020: 187)

Powodem jego medialnego sukcesu, którego nikomu później na taką skalę już nie udało się powtórzyć, było organizowanie wszystkich pracowników wokół jednego celu, jednego ideału, co zapewniało doskonałość wykonywanej pracy. W 1936 r. o. Maksymilian powiedział do braci pracujących przy wydawaniu prasy w Niepokalanowie: „Redaktorzy w «Małym Dzienniku» i w ogóle w naszych wydawnictwach muszą być przejęci naszym ideałem, w niego się wczuwać, bo inaczej nie będą spełniać należycie swojego zadania. «Mały Dziennik» wtedy będzie doskonały, kiedy będzie można podpisać: redaktor naczelny, redaktor odpowiedzialny - Niepokalana. Rozumie się, że to będzie wówczas, gdy każdy artykuł będzie tak napisany, że pod nim zamieścić byśmy mogli podpis: Niepokalana" (Klimek, 2020).

Święty Maksymilian nigdy nie chciał być człowiekiem mediów, chciał być „narzędziem w ręku [...] Jego gorliwość, umiejętność wymagania od siebie, gotowość do poświęcenia i pracy..., wszystkie te postawy były na służbie celu, który sobie wyznaczył. Nie patrzył na innych, ale uważał, że jego obowiązkiem iść za głosem Boga, szanować w pierwszym rzędzie Jego wolę. Mimo, że jego dzieła doczesne mogłyby służyć milionom, oddał życie za jednego, nieznanego mu człowieka, o którym wiedział tylko, że jest ojcem rodziny, czym zarazem wskazał na ogromną wartość rodziny. Kilka tygodni przed męczeńską śmiercią powiedział do współwięźnia: »Nienawiść nie jest siłą twórczą. Siłą twórczą jest miłość«, a decydując się umrzeć za współwięźnia »Chcę dodać innym odwagi do życia «". Zakonnik pokazał wielkość człowieka tym, którzy zatracili poczucie człowieczeństwa. Zmarł po dwóch tygodniach męczarni w bunkrze głodowym, 14 sierpnia 1941 r., dobity zastrzykiem fenolu.

Jak podaje K. Cymanow-Sosin (2020) analiza działalności Kolbego, jego wizjonerstwo oraz wyznaczniki Szkoły Etyki Mediów w Uniwersytecie Papieskim Jana Pawła II w Krakowie, na podstawie nauczania św. Jana Pawła II, pozwoliły na stworzenie modelu $4 \mathrm{P}$ - dziennikarstwa opartego na wartościach. Kolejne „P” oznaczają: profesjonalizm, pragmatyzm, pasję, pokorę. Ludzie mediów powinni korzystać zarówno z inteligencji, jak i z intuicji, by informując i kreując opinie, stawać się osobami wpływowymi na gruncie dobrze wykorzystywanej perswazji, a nigdy na gruncie manipulacji. Wydaje się, że zasadę $4 \mathrm{P}$ z powodzeniem moglibyśmy odnosić do działalności naukowo-badawczej i edukacyjnej, powołania liderów, przedsiębiorców i w zasadzie wszystkich, którzy zdają sobie 
sprawę z wpływu, jaki mogą mieć na otaczającą rzeczywistość i chcieliby ją przekształcać w duchu poszukiwania prawdy i miłości.

\section{Podsumowanie}

W świetle przedstawionych rozważań okazuje się, że św. M.M. Kolbe, człowiek o wielkiej miłości do Niepokalanej, którą udowadniał całym swoim życiem aż po męczeńską śmierć, był również wybitnym przedsiębiorcą i menadżerem, człowiekiem wszechstronnie wykształconym i utalentowanym, znającym bardzo dobrze ówczesne uwarunkowania społeczno-gospodarcze Polski i świata, odznaczającym się profesjonalizmem, pasją i determinacją w realizacji przyjętego nadrzędnego celu. Zarządzając Niepokalanowem w Polsce i Japonii, spełniał wszystkie wymienione powyżej postulaty formułowane w odniesieniu do liderów biznesu.

„Człowiek współczesny nie przestał być istotą religijną, bo żadne najdoskonalej sprawne narzędzie nie ochroni go przed lękiem i nie wyjaśni mu sensu istnienia. Człowiek współczesny - twórca i użytkownik cywilizacji technicznej - kroczy natomiast ku coraz szerszym horyzontom zwątpienia [...] człowiek współczesny - świadomy władca wszystkich wyzwolonych przez siebie mocy - czuje się nadal bezsilny" (Szczepański, 1983: 180-181). Aby w jakikolwiek sposób starać się temu przeciwdziałać, należy uświadamiać młodemu człowiekowi współczesne zagrożenia medialne, manipulacje i presje, jakim jest nieustannie poddawany, rolę właściwego informowania się, ciągłego poszukiwania prawdy i zachowania wewnętrznej wolności w podążaniu za prawdziwymi wartościami. Szczególną funkcję w tym zakresie mogą spełnić studia przykładowe, do których działalność św. M.M. Kolbego wydaje się szczególnie predystynowana.

\section{Literatura}

References

Adamczyk, J. (2008). Społeczna odpowiedzialność przedsiębiorstw. Warszawa: Teoria i Praktyka PWN.

Alvey, J.E. (2000). An introduction to economics as a moral science. International Jurnal of Social Economics, 27(12).

ANNALES. Etyka w życiu gospodarczym. T. 16. (2013). Łódź: Wydawnictwo Uniwersytetu Łódzkiego.

Bay, D., McKeage, K., McKeage, J. (2010). An historical perspective on the interplay of Christian thought and business ethics. Business and Society, 49(4), 652-676.

Borowiec, M. (2006). Etyczne aspekty globalizacji w procesie kształtowania przedsiębiorczości. Przedsiębiorczość - Edukacja [Entrepreneurship - Education], 2, 185-192.

Borowiec, M. (2013). Etyka chrześcijańska w kształtowaniu ładu moralnego w biznesie w warunkach kryzysu społeczno-gospodarczego. Przedsiębiorczość - Edukacja [Entrepreneurship - Education], 9, 34-47.

Borowiec, M., Rachwał, T. (2011). Kształtowanie postaw przedsiębiorczych na lekcjach geografii wyzwaniem edukacyjnym w procesach globalizacji. Przedsiębiorczość - Edukacja [Entrepreneurship - Education], 7, 321-332.

Borowiec-Gabryś, M., Kilar, W., Rachwał, T. (2018). Przedsiębiorczość jako kompetencja przyszłości. W: S.M. Kwiatkowski (red.), Kompetencje przyszłości. Warszawa: Wydawnictwo FRSE.

Cavanaugh, W.T. (2008). Pożarci. Gospodarka a powołanie chrześcijańskie. Warszawa: Fronda.

Chałas, K. (2018). Przyszłość należy do świadomych i aktywnych obywateli. Jakie kompetencje są im niezbędne? Jak skutecznie je kształtować? (perspektywa aksjologiczna). W: S.M. Kwiatkowski (red.), Kompetencje przyszłości. Warszawa: Wydawnictwo FRSE. 
Cornwall, J.R., Naughton, M.J. (2003). Who is the good entrepreneur? An exploration within the catholic social tradition. Journal of Business Ethics, 44(1/2), 61-75.

Cortright, S.A., Naughton, M.J. (2002). Rethinking the purpose of business. Interdisciplinary essays from Catholic social tradition. Notre Dame: Notre Dame University Press.

Cymanow-Sosin, K. (2020). Wyznaczniki dziennikarstwa preewangelizacyjnego - kompozycja standardów w oparciu o model 4P, Kultura - Media - Teologia, 41, 175-191.

Foks, M., (2017, 17 października). 5 niezwykłych świętych liderów i ich przepis na rozwój biznesu. Pozyskano z: https://pl.aleteia.org/2017/10/17/5-niezwyklych-swietych-liderow-i-ich-przepis-narozwoj-biznesu/

Galata, S. (2007). Biznes w przestrzeni etycznej. Motywy, metody, konsekwencje. Warszawa: Difin.

Gnyszka, M. (2018, 18 sierpnia). Ojciec Maksymilian Kolbe - patron wszystkich przedsiębiorców. Pozyskano z: https://pl.aleteia.org/2018/08/18/ojciec-maksymilian-kolbe-patron-wszystkichprzedsiebiorcow/

Greenleaf, R.K. (1970). The servant as leader. Indianapolis. In: The Robert K. Greenleaf Center.

Grochmal, S. (2017). Zrównoważony rozwój w przedsiębiorstwach ekonomii komunii. Ekologiczny wymiar pracy i zarządzania w biznesie. Czasopismo Psychologiczne - Psychological Journal, 23(2), 319-325.

Gronbacher, Gregory M.A.(1999). Personalizm ekonomiczny. Lublin: Instytut Liberalno-Konserwatywny.

Haromszeki, Ł., Jarko, P. (2014). System wartości menadżerów i pracowników niższego szczebla w świetle badań porównawczych. Społeczeństwo i Ekonomia, 2(2), 34-50.

Jacko, J.F. (2007). Typy i funkcje autorytetu w czasach nieufności. W: G.P. Maj (red.), Komunikacja marketingowa w czasach nieufności. Radom: Wyższa Szkoła Handlowa w Radomiu, 19-31.

Kędzierski, L. (2016). Ekonomia komunii. Studia Gdańskie. Wizje i rzeczywistość, XIII.

Klimek, A.A., (2020, 13 stycznia). Czy media sq ważniejsze niż kościoły?. Pozyskano z: https://www. opiekun.kalisz.pl/czy-media-sa-wazniejsze-niz-koscioly/

Kosmana, I. (2019, 29 września). Co święty Maksymilian ma do powiedzenia wspótczesnemu biznesmenowi?. Pozyskano z: https://towarzystwabiznesowe.pl/co-swiety-maksymilian-ma-do-powiedzenia-wspolczesnemu-biznesmenowi/

Kowalik, S. (2006). Czy potrzeba nam autorytetów na świecie? (Lustereczko, lustereczko, powiedz przecie, czy potrzeba nam autorytetów na świecie?. Ruch Prawniczy, Ekonomiczny i Socjologiczny, $\operatorname{LXVIII}(2)$.

Król, P., Leśniak, M. (2012). Kościół o powołaniu lidera biznesu. W: M. Leśniak, G. Piątek, P. Król (red.), Etyka $i$ duchowość pracodawcy XXI wieku, 30-lecie encykliki Jana Pawła II Laborem exercens. Kraków: Wydawnictwo UNUM, 81-88.

Książek, M. (2018). Wyzwania medialne ruchu „Europa Christi”. Biuletyn SAWP KUL, XIII, 15(2), 177-186.

Leśniak, M. (2012). Odpowiedzialność w świecie biznesu na podstawie nauczania społecznego Kościoła. W: M. Leśniak, G. Piątek, P. Król (red.), Moralna odpowiedzialność ludzi biznesu. Kraków: Wydawnictwo UNUM, 57-80.

Łażewska, D. (red.). (2013). Autorytet w wychowaniu i edukacji. Józefów: Wydawnictwo Wyższej Szkoły Gospodarki Euroregionalnej im. Alcide De Gasperi w Józefowie.

Mariański, J. (2000). Moralne wymiary wolnego rynku w świetle społecznego nauczania Kościoła. Ateneum Kapłańskie, 134(1).

Melé, D., Fontrodona, J. (2017). Christian Ethics and Spirituality in Leading Business Organizations: Editorial Introduction. Journal of Bussines Ethics, 145,:671-679. https://doi.org/10.1007/s10551016-3323-3

Napiórkowski, M., (2021, 16 lutego). Autorytety: czy obecnie ich potrzebujemy?. Pozyskano z: https:// nno.pl/autorytety-czy-obecnie-ich-potrzebujemy/

Operacz, J. (2017, 07 lutego). Przedsiębiorca i menedżer, wzór dla ludzi biznesu. Św. Maksymilian, jakiego nie znacie. Pozyskano z: https://pl.aleteia.org/2017/02/07/przedsiebiorca-i-menedzer-wzor-dlaludzi-biznesu-sw-maksymilian-jakiego-nie-znacie/ 
Papieska Rada IUSTITIA ET PAX. (2012). Powołanie lidera biznesu. Refleksja. Kraków: Wydawnictwo Księży Sercanów DEHON.

Parris, D.L., Peachey, J.W. (2013). A systematic literature review of servant leadership theory in organizational contexts. Journal of Business Ethics, 113, 377-393.

Piątek, G. (2021, 29 października). Wszyscy święci przedsiębiorcy. Pozyskano z: https://duszpasterstwotalent.pl/wszyscy-swieci-przedsiebiorcy/

Piontek, W. (2019). Kształtowanie przedsiębiorczości jako narządzie uwalniania potencjału gospodarczego społeczeństwa i rozwoju społeczno-gospodarczego. W: T. Rachwał (red.), Kształtowanie kompetencji przedsiębiorczych. Warszawa: Wydawnictwo FRSE.

Przemówienia Ojca Maksymiliana M. Kolbego 1912-1941. (2020). Warszawa: Wydawnictwo Matris.

Przybylski, B. (2013). Autorytet w kryzysie czy brak zapotrzebowania na autorytety? Znaczenie autorytetu dla młodzieży zaangażowanej w życie polityczne Polski. Przegląd Pedagogiczny, 2, 62-70.

Rachwał, T. (2005). Kształtowanie postaw uczniów na lekcjach podstaw przedsiębiorczości. Przedsiębiorczość - Edukacja [Entrepreneurship - Education], 1, 137-144.

Rogowski, R. (2002). Koncepcja personalizmu ekonomicznego Gregory Gronbacher'a. Roczniki EKPU, $1,331-336$.

Ryszka, Cz. (2021). Wiara i ofiara. Życie, dzieło i epoka św. Maksymiliana M. Kolbego. Kraków: Biały Kruk.

Szczepański, J.J. (1983). Święty. W: Święty naszych czasów. Beatyfikacja i kanonizacja Ojca Maksymiliana Kolbego. Warszawa: Instytut Wydawniczy Pax.

Terlikowski, P.T. (2017). Maksymilian M. Kolbe. Biografia świętego męczennika. Kraków: Esprit.

Weber, M. (2004). Racjonalność, władza, odczarowanie. Poznań: Wydawnictwo Poznańskie.

Weber, M. (2011). Etyka protestancka a duch kapitalizmu, tłum. D. Lachowska. Warszawa: Wydawnictwa Uniwersytetu Warszawskiego.

Zarządzanie z ludzką twarza. Personalizm jako narzędzie rozwoju firm, organizacji i instytucji publicznych. (2018). Warszawa: Laboratorium „Więzi”.

Żukowska, J. (2018). Aksjologia i pomiar wartości w gospodarce cyfrowej. Ujęcie filozoficzno-antropologiczne, ekonomiczne i eschatologiczne. Warszawa: Wydawnictwo Szkoły Głównej Handlowej.

Monika Borowiec-Gabryś, dr, Uniwersytet Pedagogiczny im. Komisji Edukacji Narodowej w Krakowie, Instytut Geografii, Katedra Przedsiębiorczości i Gospodarki Przestrzennej. Doktor nauk o Ziemi w zakresie geografii, adiunkt w Instytucie Geografii Uniwersytetu Pedagogicznego w Krakowie. Jej zainteresowania badawcze koncentrują się wokół problematyki gospodarki opartej na wiedzy, roli szkolnictwa wyższego i ośrodków naukowych w procesie kształtowania społeczeństwa informacyjnego, procesów transformacji społeczno-gospodarczej, ze szczególnym uwzględnieniem procesów globalizacji i integracji europejskiej, a także problematyki przedsiębiorczości.

Monika Borowiec-Gabryś, PhD, Pedagogical University of Krakow, Institute of Geography, Department of Entrepreneurship and Spatial Management. PhD in Natural Sciences (Geography), associate professor at the Pedagogical University of Krakow, Institute of Geography. Scientific interests: knowledge-based economy, role of higher education and academic centres in processes of socio-economic transformation, processes of globalisation and European integration.

ORCID: https://orcid.org/0000-0001-6234-7606

\section{Adres/Address:}

Uniwersytet Pedagogiczny im. Komisji Edukacji Narodowej w Krakowie

Instytut Geografii

Katedra Przedsiębiorczości i Gospodarki Przestrzennej

ul. Podchorążych 2

30-084 Kraków, Poland

e-mail: monika.borowiec-gabrys@up.krakow.pl 